\title{
STRATEGI PENGUATAN KOMPETENSI GURU PENDIDIKAN AGAMA ISLAM
}

\author{
ZAENURI
}

Dosen UPI Bandung

\begin{abstract}
ABSTRAK
Di tengah-tengah masyarakat banyak ditemukan peserta didik yang telah diajar, dibimbing dan dilatih oleh pendidik (kiyai, ustadz, guru) tetapi tidak banyak mengalami perubahan. Dari sinilah para ahli pedagogi menemukan fakta bahwa faktor utama dari tidak terjadinya perubahan pada peserta didik itu adalah karena peserta didiknya itu sendiri yang tidak mau berubah. Fakta inilah yang kemudian menjadi bahan diskusi dan diwacanakan dengan sebutan HEUTAGOGI. Kenyataan dan pernyataan itulah kemudian diilustrasikan sebagai peristiwa petani yang ulet dan rajin (profesional) mengelola sawah dengan bibit unggul dan tanah sawah yang bagus serta dikelola dengan baik, akan tetapi petani tidak banyak memperoleh hasil sesuai dengan yang diharakan. Perkembangan dan perubahan makna terus berkembang sehingga pedagogi berarti seni mengajar.mendidik. Perkembangan jaman dan pemikiran terus berjalan sehingga muncul istilah pedagogi tradisional, pedagogi transformasi, padagogi modern dan bahkan pedagogi posmodern. Sudah barang tentu, perubahan makna pedagogi pun terjadi sesuai dengan perkembangan istilah itu sendiri.
\end{abstract}

Kata Kunci: Pedagogi, Andragogi dan Heutagogi

\section{A. Pendahuluan}

Dalam dunia pendidikan, ada dua istilah yang sudah dikenal oleh para guru yaitu kata pedagogi dan andragogi. akan tetapi, belakangan ditemukan istilah ketiga yaitu heutagogi. kata paedagogie atau paedagogos berasal dari bahasa Yunani kuno. Kata ini terdiri dari dua suku kata yaitu paedos yang berarti "anak" dan agogo yang berarti "saya membimbing". Belakangan kata pedagogi yang bermakna "pergaulan bersama anak-anak". Kata pedagogi dalam bahasa Inggrisnya education, yang berarti "proses perbuatan untuk memperoleh pengetahuan"

Di tengah-tengah masyarakat banyak ditemukan peserta didik yang telah diajar, dibimbing dan dilatih oleh pendidik (kiyai, ustadz, guru) tetapi tidak banyak mengalami perubahan. Dari sinilah para ahli pedagogi menemukan fakta bahwa faktor utama dari tidak terjadinya perubahan pada peserta didik itu adalah karena peserta didiknya itu sendiri yang tidak mau berubah. Fakta inilah yang kemudian menjadi bahan diskusi dan diwacanakan dengan sebutan HEUTAGOGI.

Hanya saja kita tetap kembali ke pengertian pendidikan semula proses perubahan sikap dan tingkah laku seseorang atau sekelompok orang dalam usaha mendewasakan manusia melalui upaya pengajaran dan pelatihan (KUBI, 1999:232). Perkembangan makna juga terjadi pada kata ANDRAGOGI yang semula artinya "pendidikan bagi orang dewasa". Belakangan kata dewasa mulai diperdebatkan. Apakah dewasa usia, dewasa sosial, dewasa pengetahuan. Terlepas dari perubahan kata dan makna yang terjadi pada pedagogi dan andragogi. Tujuan akhir dari pendidikan adalah terjadinya perubahan pada peserta didik (santri, murid, siswa) setelah mereka mengikuti pembelajaran. Berubah kognisinya, berubah afeksinya dan pasti berubah psikomotornya.

Pendidikan dipelajari dari segi konsep, sebagian ahli bahasa meyakinkan konsepnya bahwa, pendidikan berasal dari bahasa Inggris yaitu education (Ngalim Purwanto, 1989); atau berasal dari bahasa Arab: al- 
ta'lim, al-tarbiyah atauAl-ta'dib, (al-Atas, 1987). Pada saat yang sama, sebagian terminolog berpendapat bahwa pendidikan berasal dari bahasa Yunani yaitu paedagogie (Abdurahman Saleh, 1989) yang artinya mirip dengan kata-kata education, al-ta'lim, al-tarbiyah atau al-ta'dib yang menitik beratkan pada upaya pembimbingan terhadap anak, sehingga menjadi manusia dewasa.

Kata pembimbingan sendiri hampir mirip maknanya dengan kata pembinaan, pengajaran atau pelatihan. Padahal, sebagian ahli menyebutkan ada perbedaan mendasar antara pendidikan dengan beberapa kata tadi, misalnya Drost (1999) yang dalam tulisannya membedakan antara pendidikan dengan pengajaran. Perbedaan itu akan kentara ketika diterapkan kepada proses transformasi ilmu pengetahuan, keterampilan dan pengalaman seseorang kepada orang lain. Kata guru misalnya, kata ini lebih tepat disejajarkan dengan kata pengajar yang bertugas memberikan pengajaran kepada peserta didik di dalam kelas.

Pendidikan berhubungan erat dengan investasi kemanusiaan yang sangat potensial dalam usaha meningkatkan pendapatan hasil kerja, karena itu terdapat siklus yang saling berkaitan antara pendidikan dengan pendapatan dan kesejahteraan hidup. Ini artinya bahwa, pendidikan berkaitan dengan penampilan kerja, penampilan kerja berkaitan dengan produktivitas, produktivitas berkaitan dengan income, income berkaitan erat dengan kesejahteraan. Sehingga pada akhirnya, kesejahteraan sangat berkaitan sekali dengan keikut sertaan masyarakat dalam memajukan pendidikan, salah satunya adalah masyarakat mempercayakan anak-anaknya dimasukkan ke lembaga-lembaga pendidikan.

Atas dasar itulah barangkali alasan mengapa sebagian ahli pendidikan seperti Longevel menggolongkan hakikat manusia ke dalam tiga golongan yaitu sebagian manusia ada yang digolongkan sebagai educable animal yaitu makhluk yang dapat dididik, sebagian yang lain manusia digolongkan sebagai animal educandum yaitu makhluk yang harus dididik, dan sebagian yang lainnya digolongkan sebagai makhluk Allah yang dapat menerima dan sekaligus memberikan materi pendidikan atau homo education. Seseorang atau sekelompok orang yang menerima materi pendidikan (educable animal) disebut peserta didik (student); seseorang atau sekelompok orang yang memberikan materi pendidikan (animal educandum) disebut pendidik (teacher). Sementara itu, para pakar, praktisi dan pemerhati pendidikan dapat digolongkan ke dalam kelompok homo education yakni karena peranannya di samping mereka sering memberikan kontribusi pemikirannya juga mereka selalu melakukan berbagai pengkajian dan penelitian tentang sesuatu yang akan ditulis, dilaporkan dan disebarluaskan kepada masyarakat.

\section{Profesionalisme dan Kompetensi GPAI}

Profesionalisme guru. Secara sederhana dapat digambarkan sebagai suatu pekerjaan apapun bentuknya akan dinilai profesional, jika out-put yang dihasilkannya dapat memenuhi keinginan semua pihak. Semua bentuk pekerjaan bisa dikatakan professional, jika pekerjaan itu dilakukan oleh mereka secara khusus bukan karena tidak bisa melakukakan pekerjaan lainnya. Begitu pula profesi guru. Guru adalah semua orang yang berwenang dan bertanggung jawab terhadap penididikan murid, baik secara individual atau klasikal, baik di sekolah maupun diluar sekolah (Syaiful Bahri Djamarah, 2000: 32). Ini artinya bahwa, guru dalam melaksanakan tugasnya baik di lingkungan pendidikan formal dan pendidikan non formal, dituntut untuk mendidik dan mengajar sesuai bidang ilmu pengetahuan yang dimilikinya. Dalam PP No. 19 tahun 2005 tentang Standar Pendidikan pasal 28 dan 29 yang menyebutkan bahwa pendidik harus memiliki kualifikasi akademik dan kompetensi sebagai agen pembelajaran, sehat 
jasmani dan rohani, serta memiliki kemampuan untuk mewu-judkan tujuan pendidikan nasional.

Guru Pendidikan Agama Islam (GPAI) merupakan salah satu faktor yang sangat penting dalam meningkatkan kualitas pendidikan. Karena GPAI di samping mempunyai peran mentransfer ilmu pengetahuan, juga membantu proses internalisasi moral kepada siswa. Jadi GPAI diharapkan mampu membawa anak didiknya menjadi manusia yang "sempurna" baik lahiriah maupun batiniah. Dari sini seorang GPAI dituntut untuk bertindak secara profesional agar proses belajar mengajar dapat berjalan dengan maksimal.

Profesionalitas guru agama meliputi hal-hal berikut ini:

1. Menguasai landasan kependidikan, meliputi: Mengenal tujuan pendidikan nasional untuk mencapai tujuan, Mengenal fungsi sekolah dalam masyarakat, Mengenal prinsip-prinsip psikologi pendidikan yang dapat dimanfaatkan dalam proses belajar mengajar.

2. Menguasai bahan pengajaran, meliputi: Mengusai bahan pengajaran kurikulum pendidikan pendidikan dasar dan menegah, Mengusai bahan pengajara

3. Menyusun program pengajaran, meliputi: Menetapkan tujuan pembelajaran, Memiliki dan mengembangkan bahan pembelajaran, Memiliki dan mengem-bangkan media pengajaran yang sesuai, Memilih dan memamfaatkan sumber belajar

4. Melaksanakan program pengajaran, meliputi: Menciptakan iklim belajar mengajar yang tepat, Mengatur ruangan belajar, Mengelola interaksi belajar mengajar

5. Menilai hasil belajar mengajar yang telah dilaksanakan, meliputi: Menilai prestasi murid untuk kepentingan pengajaran, Menilai proses belajar mengajar yang telah dilaksanakan.
Dari keterangan di atas dapat dikermukakan bahwa guru profesional adalah guru yang mempunyai strategi mengajar, menguasai bahan, mampu menyusun program maupun membuat penilaian hasil belajar yang tepat. Selain itu seorang guru yang profesional juga harus mampu memotivasi siswanya untuk semangat dalam belajarnya. Mengenai hal ini, ada beberapa kemampuan yang harus dimiliki oleh guru yaitu :

1. Menggunakan cara atau metode dan media mengajar yang bervariasi. Dengan metode dan media yang bervariasi kebosanan pun dapat dikurangi atau dihilangkan.

2. Mmemilih bahan yang menarik minat dan dibutuhkan siswa. Sesuatu yang dibutuhkan akan menarik perhatian, dengan demikian akan membangkitkan motivasi untuk mempelajarinya.

3. Memberikan saran antara lain ujian semester, ujian tegah semester, ulangan harian dan juga kuis.

4. Memberikan kesempatan untuk sukses. Bahan atau soal yang sulit yang hanya bisa dicapai siswa yang pandai. Agar siswa ysng kurang pandai juga bisa maka diberikan soal yang sesuai dengan kepandainnya.

5. Diciptakan suasana belajar yang menyenangkan. Dalam hal ini di lakukan guru dengan cara belajar yang punya rasa persahabatan, punya humor, pengakuan keberadaan siswa dan menghindari celaan dan makian.

6. Mengadakan persaingan sehat melalui hasil belajar siswa. Dalam per-saingan ini dapat diberikan pujian, ganjaran ataupun hadiah.

Kompetensi GPAI. Dalam Kamus Besar Bahasa Indonesia, kompetensi adalah kewenangan (kekuasaan) untuk menentukan (memutuskan) sesuatu. Competence (Inggris) adalah kecakapan dan kemampuan. Karena itu, kompetensi guru adalah dapat diartikan sebagai kenampuan seorang guru dalam 
melaksanakan tugas dan kewajiban serta bertanggung jawab sesuai tugas pokok dan fungsi (TUPOKSI) akademiknya. Kompetensi guru dipengaruhi oleh dua faktor yaitu faktor latar belakang pendidik (akademik) dan pengalaman mengajar. Kompetensi akademik guru dapat diartikan sebagai kemampuan dan kewenangan guru dalam menjalankan profesi keguruannya berdasarkan potensi akademik keilmuan yang dimilikinya (Djamarah, 2000: 130132).

Kalau kompetensi berarti kemampuan atau kecakapan, maka hal ini erat kaitannya dengan pemilikan pengetahuan, kecakapan dan/atau keterampilan guru. Dengan demikian, kompetensi merupakan perpaduan dan pengetahuan, keteram-pilan, nilai dan sikap yang di refleksikan dalam kebiasaan berpikir dan bertindak yang diperagakan guru. Dari sinilah kemudian dikemukakan bahwa, kompetensi guru merupakan syarat utama dalam proses pembelajaran. Kompetensi di sini didefinisikan sebagai pemilikan pengetahuan (konsep dasar keilmuan), keterampilan yang dibu-tuhkan dalam menyelesaikan suatu pekerjaan dilapangan, dan kemampuan sebagai guru dalam melaksanakan tugasnya

Kompetensi guru terdiri dari, kompetensi pribadi, kompetensi profesional, kompetensi personal/kepribadian, kompetensi social dan kompetensi keagamaan. Di dalam kompetensi itu semua, terdapat kemampuan yang terdiri dan kemampuan mengelola kelas, keterampilan mengelola bahan, keterampilan proses belajar meng-ajar. Ini yang dimaksud dengan kompetensi pedagodik.

1. Kompetensi Profesional. Kompetensi profesional adalah kemampuan guru dalam penguasaan bahan ajar secara penuh dan juga cara-cara mengajarkannya secara pedagogis dan metodis. Kemampuan guru dalam bidang ilmu pengetahuan dan teknologi yang dimilikinya.
2. Kompetensi Personal/kepribadian. Kompetensi personal/kepribadian guru adalah berkaitan dengan potensi psikologis guru dalam menjalankan tugas pokok dan fungsinya sebagai tenaga pendidik. Kompetensi personal dapat dikemukakan melalui tiga cakupan yaitu : 1) penampilan sikap positif terhadap keseluruhan tugasnya seba-gai guru dan terhadap keseluruhan situasi pendidikan; 2) pemahaman, penghayatan, dan penampilan nilai-nilai yang seyogyanya dimiliki guru; dan 3) penampilan sebagai upaya untuk menjadikan dirinya sebagai panutan dan teladan bagi para sisiwanya.

3. Kompetensi Sosial. Kompetensi sosial guru adalah kemampuan guru dalam berkomunikasi atau dalam berhubungan dengan para siswanya, sesama teman guru, kepala sekolah, pegawai tata usaha, dan dengan anggota masyarakat dilingkungannya (Arikunto, 1990). Dengan maksud lain kompetensi sosial guru adalah kemampuan guru dalam berhubungan sosial dengan sesama manusia, terutama dengan orang-orang disekitarnya, seperti tetangga, kerabat, dsb.

4. Kompetensi Keagamaan. Kompetensi keagamaan guru dimaksudkan adalah, komitmen terhadap nilai, norma dan sikap serta berperilaku sesuai ajaran agama. Komitmen terhadap agama ini dapat diukur melalui ketaatan guru dalam menjalankan perintah dan menjauhi larangan Allah, mengamalkan ajaran agama yang bersendikan al-Quran, al-sunnah dan ijtihad ulama, kegairahan dalam mempelajari ilmu agama, dan aktif dalam berbagai kegiatan keagamaan.

Kesemuya bentuk kompetensi tersebut, harus selalu dijalankan tidak hanya pada saat guru PAI ketika mengajar di dalam kelas tetapi juga dimana pun dan kapanpun guru berada, kompetensi itu harus selalu dijaga dan dilestarikan. Ini artinya bahwa, Seorang guru PAI yang profesional adalah guru yang 
selain menguasai materi pelajaran yang akan diajarkan, juga menguasai cara bagaimana materi pelajaran tersebut bisa disampaikan kepada siswa dengan baik. Dengan penguasaan dari seluruh kompetensi, maka akan dihasilkan guru yang kompeten dan profesional, memiliki kepribadian yang baik, taat pada agama, dan memiliki rasa sosial yang tinggi. Dengan kalimat lain, guru PAI yang profesional adalah guru yang selain menguasai materi pelajaran, juga menguasai cara bagaimana materi pelajaran tersebut bisa disampaikan serta mampu menggunakan media belajar yang dapat memudahkan daya serap murid.

Kesemua kompetensi tersebut dapat dikelompokkan ke dalam dua kelompok besar yaitu apa yang disebut dengan istilah hard compe-tence atau soft skill dan soft competernce atau sof skill. Yang termasuk hard competence adalah kompeternsi pedagogi dan kom-petensi profesional. Sedangkan kompetensi kepribadian dan kompe-tensi sosial termasuk ke dalam soft competence atau hard skill.

Berdasarkan pengalaman di lapangan, soft competence jauh lebihpenting daripada hard competence. Perbandingan dari keduanya bisa mencapai $80 \%-20 \%$. Ini artinya, kesuksesan pendidik dalam menyampaikan pelajaras kepada peserta didik di lembaga pendi-dikan bukan karena keterampilan terknis melainkan karena kualitas diri/kepribadian yang ada poada pendidik. Dengan kata lain, kom-petensi kepribadian dan kompetensi sosial lebih utama diban-dingkan dengan kompetensi pedagogi dan kompetensi profesional.

\section{Interpersonal dan Intrapersonal:Strategi Peningkatan Kompetensi Guru PAI}

Di tengah-tengah kita, sebagian ada yang cerdas dan terampil tapi tidak menyenangkan bahkan membosankan, sebagian lainnya ada yang pintar tapi sombong. Namun, di sini juga ada yang tidak cerdas-cerdas amat tapi komunikatif. Mungkin banyak juga jumlahnya di sini yaitu guru PAI yang tidak pandai tetapi simpatik. Kalau disuruh memilih, pasti kita guru PAI yang cerdas/pandai tapi sombong dan tidak menyenangkan itu tidak sesuai dengan kompetensi Guru PAI. Kompetensi Guru PAI yaitu mereka yang 'alim (pandai), cer-das dan terampil tapi tidak sombong bahkan justru menyenangkan. Ilustrasi ini mengingatkan kita betapa pentingnya soft competences.

Untuk ini, Guru PAI sebisa mungkin mengembangkan kemampuan intra-personal skills dan interpersonal skills yaituketerampilan berkomunikasi dengan orang lain dan keterampilan mengatur diri. Di bawah ini hasil survey terhadap 20 kualitas penting yang dimiliki jawara berdasarkan rangking sebagai berikut:

1. Kemampuan Berkomunikasi,

2. Kejujuran (integritas),

3. Kemampuan Bekerjasama,

4. Kemampuan Interpersonal,

5. Berertika (akhlaq al-karimah),

6. Inisiatif (termotivasi),

7. Kemampuan Beradaptasi,

8. Daya Analitik,

9. Kemampuan mengoperasionalkan Komputer,

10. Kemampuan Berorganisasi,

11. Berorientasi pada Detail,

12. Leadership (kepemimpinan),

13. Kepercayaan Diri,

14. Ramah,

15. Sopan,

16. Bijaksana,

17. Indeks Prestasi (IP) 3,00,

18. Kreatif,

19. Humoris

20. Kemampuan Berwirausaha

\section{Strategi Peningkatan Kompetensi Akademik Guru PAI}


Kompetensi Guru PAI dinilai oleh sebagian kalangan masih belum maksimal, karena masih banyak ditemukan Guru PAI yang masih minim dalam penguasaan kompetensi. Karena itu, sebagian tokoh pendidikan mengusulkan tentang perlunya pembinaan dan pelatihan dalam upaya meningkatan dan mengembangkan kompetensi guru PAI. Upaya lain yang harus dilakukan adalah Perguruan Tinggi Agama Islam (PTAI) yang memproduksi guru PAI sudah saatnya membenahi kurikulum, terutama terkait dengan penguasaan kompetensi.

Pengembangan kompetensi akademik Guru PAI berkaitan erat dengan pengembangan profesi guru yang pada akhirnya berkaitan dengan organisasi pendidikan. Pengembangan profesi guru, tidak hanya dilakukan oleh para pendidik secara individual, tetapi secara konsep juga dibantu, diawasi dan dikordinasi oleh organisasi profesi guru. Hanya saja fungsi organisasi profesi guru seperti ini dalam bidang pendidikan masih belum tampak, karena itu tidak sedikit para pendidik mengem-bangkan profesinya gurunya secara sendiri-sendiri.

Pada hakikatnya proses pembelajaran adalah proses komunikasi yang harus diciptakan atau diwujudkan melalui penyampaian dan tukar menukar pesan/ informasi oleh setiap tenaga pengajar dan peserta didik. Pesan atau informasi dapat berupa pengetahuan, keahlian, skill, ide, pengalaman. Berdasar pada kajian histori dan ajaran-ajaran Islam, proses pembelajaran telah diterapkan oleh ulama terdahulu dengan memenuhi aspek berikut ;

1. Memberikan kemudahan dan suasana gembira.

2. Menciptakan lingkungan belajar yang kondusif.

3. Menarik minat.

4. Memberikan model perilaku yang baik.

5. Menyajikan materi yang relevan.

6. Materi pelajaran itu relevan dan penting.
7. Melibatkan emosi positif dalam pembelajaran.

8. Melibatkan semua indra dan pikiran.

9. Menyesuaikan dengan tingkat kemampuan siswa.

10. Memberikan pengalaman sukses.

11. Merayakan hasil.

Beberapa tawaran dan usulan tersebut di atas hanyalah konsep yang belum tentu sesuai dengan kopnsep dan pengalaman yang telah dimiliki guru PAI. Hanya saja melalui tawarfan/usulan tersebut paling tidak kita sebagai guru PAI saling merngingatkan bahwa kemampuan guru PAI harus selalu bertambah dan diperbaharui. Sebab, jaman dan tuntutan masyarakat akan terus selalu berubah sesuai perkembangan jaman. Ilmu pengetahuan yang telah kita miliki beberapa tahun yang lalu, dinilai bagus dan urgen pada masa itu. Namun demikian, jika diterapkan pada masa kini dan masa yang akan dating maka sesuatu yang telah kita miliki dinilai out of deth. Sehingga dibutuhkan penambahan dan pembaharuan sesuai dengan bertambahnya waktu dan perkembangnya kebutuhan/tuntutan masyarakat.

\section{Kesimpulan}

Pernyataan dan penjelasan di atas telah banyak diketahui, maka tibalah saatnya untuk mengambil kesimpulan sebagai berikut:

1. Saat ini peran guru masih sangat penting, walaupun ditengah arus kemajuan ilmu dan teknologi yang kian pesat seperti laju informasi yang bisa langsung diterima bukan dan guru, namun dan alat-alat canggih seperti TV, Radio dll. Dalam menyikapi hal ini guru dituntut dapat memerankan perannya sesuai dengan kebutuhan ataupun tuntutan masyarakat. Dalam melaksanakan tugasnya, seorang guru mempunyai tanggung jawab yang utama. Mengajar merupakan suatu perbuatan yang memerlukan tanggung awab moral yang cukup berat. 
Berhasilnya pendidikan pada siswa sangat tergantung pada pertanggung jawaban guru dalam melaksanakan tugasnya. Masalah utama pekerjaan profesi adalah implikasi dan konsekuensi pekerjaan tersebut terhadap tugas dan tanggung jawabnya. Tugas dan peran guru tidaklah terbatas di dalam masyarakat, bahkan pada hakikatnya tugas guru merupakan komponen strategis yang memiliki peran yang penting dalam menentukan gerak maju kehidupan bangsa. Keberadaan guru merupakan faktor yang penting dalam suatu bangsa yang tidak mungkin digantikan oleh yang lain.

2. Betapa sulit dan penuh tantangan kita sebagai sosok seorang GPAI, karena ternyata tupoksi kita tidak cukup hanya memberikan muatan materi saja (transfer of knowledge) melainkan kita dituntut harus bersikap sebagai orang kedua setelah orang tua siswa di rumah. GPAI adalah fokus yang sangat vital, sebab baik dan buruknya peserta didik tergantung sosok kita sxebagai GPAI. Dari sinilah kita memahami dan memulai bahwa peningkatan mutu seyogianya segera kita perbaiki dan kita tingkatkan.

3. Kompetensi guru merupakan perpaduan dan pengetahuan, keterampilan, nilai dan sikap yang di refleksikan dalam kebiasaan berpikir dan bertindak. Kompetensi guru terdiri dari, kompetensi pribadi, kompetensi profesional, dan kompetensi pedagogic yaitu kemampuan mengelola kelas, keterampilan mengelola bahan ajar, dan keterampilan proses belajar mengajar.

\section{Daftar Bacaan}

Abuddin Nata. 2001. Pemikiran Para Tokoh Pendidikan Islam. Jakarta: Grafindo Persada.

Bafadal, Ibrahim. 2003. Manajemen Peningkatan Mutu Sekolah Dasar. Dari sentralisasi menuju desentralisasi. Jakarta: Bumi Aksara.
Chan, Sam M dan Sam, Tuti T. 2005. Analisis SWOT; Kebijakan Pendidikan Era Otonomi Daerah. Jakarta: PT Rajagrafindo Persada.

John M Echols dan Hasan Shadily. 1980. Kamus Inggris Indonesia. Jakarta: Gramedia.

Mulyasa, E. 2002. Manajemen Berbasis Sekolah Konsep, Strategi dan Implementasi. Bandung: Remaja Rosdakarya.

Nurhadi. 2002. Pendidikan Kontekstual. Jakarta: Dirjen Pendidikan Lanjutan Pertama.

P. Robbins, Stephen, .1992. Essential of Organizational Behavior. America: Prentice-Hall International, Inc.

Rose, Colin. 2003. KUASA I Lebih Cepat Buku Pintar Accelerated Learning, alih bahasa Femmy Syahrani. Bandung: Kaifa.

Saiful Sagala. 2005. Konsep dan Makna Pembelajaran untuk Membantu Memecahkan Problematika Belajar dan Mengajar. Bandung: Alfabeta.

Silberman, Mel. 2002. Active Learning: 101 Strategi Pembelajaran Aktif, Yogyakarta: Yappendis.

Soekijo, $\quad$ Notoatmodjo. 2003. Pengembangan Sumber Daya Manusia. Jakarta: Rineka Cipta.

Stenberg, Robert J. 1996. How Practical and Creative Intelligence Determine Success in Life: Successfully Intelligence. America: A Plume Book.

Suwito dan Fauzan, 2003. Sejarah Pemikiran Para Tokoh Pendidikan. Bandung: Angkasa.

Wahjosumidjo. 2002. Kepemimpinan Kepala Sekolah: Tinjauan Teoritik dan Permasalahannya. Jakarta: Raja Grafindo Persada.

Wengger, Win. 2003. Beyond Teaching and Learning: Cara Praktis Menerapkan Quantum Teaching dan Learning, alih 
bahasa Ria Sirait dan Purwanto, Nuansa Bandung:

Yamin, Moh. 2009. Menggugat Pendidikan Indonesia. Belajar Dari Paulo freire dan Ki Hajar Dewantara. Jakarta : ArRuzz Medi. 